\title{
The 'Angels of Europe': Corporate Public Affairs Employees as the In-House Entrepreneurs of Europe
}

\author{
ARMÈLE CLOTEAU* \\ Laboratoire PRINTEMPS, Université de Versailles Saint-Quentin-en-Yvelines, \\ Paris - Saclay
}

\begin{abstract}
This article examines the inner workings of a private company's participation in the European policy game. The qualitative analysis shows that the promotion of a company's interests and its positioning at the level of the European Union is not self-evident and results from internal battles in which European public affairs employees play a pivotal role. Under what conditions do the European public affairs employees of a leading multinational firm endorse, manage, and promote an active position in the Brussels' polity sphere? This article highlights the process by which these 'professionals of Europe' adapt to the specific requirements of the EU and mobilise an informal network to contribute to European policy-making. These lobbyists appear as 'double entrepreneurs': as entrepreneurs on behalf of both their employers' interests and the European cause as they place themselves as the auxiliaries of EU civil servants. Maintaining a delicate balance, interest representatives occupy a position of dependence, both on their employer and on the polity field in which they valorise their 'European institutional capital'. This position allows these social agents to serve as a broker between their employer and the European arena. In doing so, they nurture the porosity between (economic) interests and the public sector, which cuts across the field of 'Eurocracy'.
\end{abstract}

Keywords: lobbying, European Union, corporate influence, policy-making, interest representation

Sociologický časopis/Czech Sociological Review, 2018, Vol. 54, No. 6: 837-857

https://doi.org/10.13060/00380288.2018.54.6.432

In 2016, the chief of the Brussels office of a large multinational corporation summoned together the network of professionals in charge of European public affairs working for this corporation in different European countries. He welcomed his guests for this annual two-day workshop with the following words: 'What connects us all, apart from the company we currently work for, is the European project. We work here, we may work elsewhere tomorrow-different city, different employer, but the same mission: Europe. What are we, if not the "Angels of

* Direct all correspondence to: Armèle Cloteau, Université de Versailles Saint-Quentin-enYvelines, Paris, France, e-mail: armele.cloteau@gmail.com.

(C) Sociologický ústav AV ČR, v.v.i., Praha 2018 
Europe"?' The performative dimension of this speech suggests that what unites these employees, all working for different units of the same leading multinational company in the agro-food sector, is not business objectives or the action of representing the interests of their employer as much as it is 'Europe', which is seen here as a cause. This article explores the underlying mechanisms of a company's contribution to policy-making at the level of the European Union (EU).

According to developing literature in European Studies, the process of standard-setting - broadly understood as norm formation or regulation-should not be understood as being the exclusive domain of states or governmental authorities, as it increasingly involves diverse and polymorphous non-state actors [Stone Sweet, Sandholtz and Fligstein 2001]. Scholars mostly focus on the public perspective or on the standard-setting processes [Lequesne and Surel 2004]. Nonstate actors and especially business interest groups are often expected to hold pre-existing competencies to contribute to policy-making regardless of the specificities of the targeted level of governance and to spontaneously share harmonised views, both internally and among themselves within federations [Offerlé 2009]. This article presents empirical evidence to pursue M. Offerlé's position that a collective interest does not pre-exist until a group of agents tries to voice it. The mere fact that an EU-based multinational company operates in multiple EU countries does not necessarily mean that its interests and political goals vis-à-vis the EU polity sphere are clear-cut. I suggest considering each multinational corporation as a group of sub-entities with competing interests that they negotiate internally, resulting in a position that is carefully weighed and then promoted in a specific policy arena. By assessing a dimension that reverses the classical view about EU lobbying, this article offers insight into the inner workings of a company's voice at the European level. It explores the internal dissonances of a company from the perspective of its EU office representatives based in Brussels, taking a closer look at its mobilisation efforts to contribute to standard-setting activities.

Over the past ten years, there has been a renewal of research on European actors that, which has tried to go beyond the limitations of the existing literature by more closely studying the individuals who belong to EU institutions or are in close contact with them. By analogy with Bourdieu's bureaucratic field, the theory of the field of Eurocracy provides valuable tools for unravelling the complexities of the European polity [Georgakakis and Rowell 2013]. Alongside this recent development of an empirical political-sociology approach in European Studies, my case study aims to contribute to the analysis of the complex web of relationships among different actors participating in the daily functioning of institutional Europe. In reaching beyond the mythicised representations of lobbying activities, the ambition of this article is twofold: first, to document the conditions that facilitate participation in European policy-making for this particular type of European professionals; and second, to illustrate the permeability of private and public interests. Beyond specifying the relationships between EU institutions and groups of actors involved in European regulation, my empirical research seeks to document the underpinning of the lobbyists' participation in 
the various European arenas-from expert groups to meetings with Members of the European Parliament-which in fine affect the standard-setting processes. Following the work of W. Streeck and P. C. Schmitter [1991], which highlights the important role of the indirect lobbying work of European business federations (notably managing members), I argue that engaging with regulators and drafting amendments to European laws constitutes the 'front stage' of interest representation practices. These activities are only possible thanks to the less visible part of the work, which involves coordinating a large network of 'Angels of Europe'. This network is composed of around fifty employees, located for the most part in the national bureaus of the firm. On top of their daily activities, they undertake work related to European policies, which is coordinated by a small team of ten employees-central to this study-located in Brussels.

By examining the formal and informal structure that allows a private company to take part in the EU policy game, this paper shows that the promotion of a company's interests and its positioning at the European level is far from self-evident. On the contrary, it results from internal battles within the company in which European public affairs employees play a pivotal role, stretching the organisation between multiple and sometimes conflicting aspirations. Adapting to the specific requirements of the field of Eurocracy implies struggles for authority on the margins of that field, involving the determination of legitimate professional profiles and capital resources. This paper shows the conditions under which European public affairs employees get to endorse, manage, and promote the company's active positioning in the Brussels' polity sphere. The question therefore is less 'why lobby Brussels?' and more 'how is lobbying constructed within an organisation?' This article highlights the process by which these European professionals are able to mobilise an informal network of professionals to support their daily activities by granting them financial and material resources. These professionals thus play a 'double entrepreneurship' role: they act as entrepreneurs on behalf of their employer's cause as well as entrepreneurs on behalf of the European cause by positioning themselves as the auxiliaries of EU civil servants. They maintain a delicate balance, as each role is necessary to the other. The paper reveals lobbyists' activities from the inside, notably in the way they engage in building Europe much in the same way that European civil servants do [Shore 2000; Georgakakis 2017].

If there are some embedded studies that have been conducted from within EU institutions or trade unions [Busby and Belkacem 2013; Ross 1995; Roullaud 2017], rare are the ones on important corporate lobbies. This paper is based on field research and ethnographic observations performed during a six-month internship at the Brussels office of a leading multinational agro-food company, ten interviews conducted with members of its network across European countries, and the study of internal documents. To broaden the scope, multiple observations and interviews were conducted within other economic sectors, along with consultation of grey literature. In this article, I mostly focus on a specific group of employees, members of the European public affairs office of the selected firm, who play a connecting and pivotal role between EU officials and their employer. 
This office, geographically located at the heart of European Union institutions in Brussels, is composed of five general employees in charge of EU policies in a broad sense-who are the key players in this paper-and five lawyers dedicated to International and European competition law. Despite limited human and financial resources 1 - this office officially receives resources only for its everyday functioning and not for handling specific projects, such as campaigns or events organisation-it remains the sole and permanent office within the company with the exclusive function of dealing with 'European issues'. As a result, Europe appears to be both the raison d'être and the professional focus of the members of this group [Georgakakis 2002]. These well-established lobbyists often present themselves as 'the voice of the company at the European level'. The multiplicity of the roles and self-representations of this group within and outside the company brings particular insights to this article and justifies their centrality in the analysis.

The article is organised along two axes: first, it apprehends the promotion of the European level as the right level of action towards other services of the same firm, and then it analyses the mobilisation and management of an informal network of European public affairs professionals developed across the EU.

\section{Within the firm: promoting Europe as the right level of action}

Despite the increased influence of European policies in a number of fields, multinational corporations, managed at a global level, display unequal levels of engagement in the European polity sphere [Michel 2013]. My empirical research emphasises that investing in this level of governance (e.g. by financing an office in the neighbourhood of EU institutions) is often considered by top executives located at the headquarters of the company as 'worthless' or an 'intellectual pastime' not necessarily in line with their business priorities $(a)$. In return, European public affairs employees position themselves as entrepreneurs of European norm creation and therefore strive to make their colleagues and superiors 'buy Europe' (b).

\section{a. Walking the thin line between business and politics: the Brussels office amidst tensions and self-legitimation}

Recent research demonstrates that 'European lobbyists' form both a European group (in the sense that they are largely independent from the logic of the national arenas) and a specialised group with specific skills-true European profes-

\footnotetext{
${ }^{1}$ According to the transparency register of the European Parliament (where lobbying information is self-reported by the interest groups themselves), the cost dedicated by the selected firm to EU lobbying activities ranges from 300000 to 399000 EUR annually. This number places the firm slightly below the average of its main competitors in terms of both financial and human resources.
} 
sionals [Georgakakis 2002; Michel 2005] engaged in the process of constructing Europe alongside other political and administrative groups. Over time, authors have witnessed [Courty and Michel 2013; Laurens 2018] a proliferation of economic- and public-interest lobbying of European Union institutions, largely produced by European institutions themselves. Indeed, following the concomitant transfer of responsibilities to the European Union and changes in institutional procedures, as well as the globalisation of economic activities, there has been an increase in the number of European-level interest associations and national interest associations with offices in Brussels and an overall increase in the direct representation of lobbyists in Brussels [Laurens 2018]. The organisations that become active in shaping European policies are the result of a mobilisation that depends not only on available resources but also on 'group entrepreneurs' who create organisations [Offerlé 1994]. These entrepreneurs adapt groups and their type of representation to institutional expectations. S. Mazey and J. Richadson [1996] have in their seminal work shown that the European Commission has long favoured Eurogroups (European federation of national interest groups), which forced those very organisations to reorganise themselves internally according to the European dimension and European constraints during the phase of European integration.

The company at the centre of this study has European roots, but its European bureau only dates back to the 2000s. Before then, its interests were- and still arerepresented via European sectorial and business associations. They themselves have been based in Brussels since the very first developments of the European Economic Community in the early 1960s. In addition, external affairs employees from the headquarters of the company used to engage with European institutions personnel on an ad-hoc basis, travelling over the day for the purpose of a specific meeting. On rare occasions, external affairs employees from national offices who had special expertise in the topic of the policy concerned may have joined them. In spite of its European history, it took several restructuring processes within the organisation to adapt to a Europe-wide form of business. According to a former employee's testimony on the office's pre-European period, the firm's European policy 'had no consistency', 'dreadfully lacked coordination', and relied mostly on its more than twenty memberships in European federations. Over the years, some external affairs employees at the company's headquarters acquired the specialised skills and specific resources that in recent literature have been called 'European institutional capital' [Georgakakis and Rowell 2013; Laurens 2018]. They eventually managed to move to Brussels, the core location of their activities. To this extent, the decision to invest in the European sphere cannot be seen as the result of a purely mechanical process: Because there are Community institutions whose competences make them of direct interest to organisations does not mean that these organisations will automatically open a representative office in Brussels [Morival 2013]. This also depends on the original structure of the organisation (a national division in this case), which constrains the progressive adaptation of economic activities and interest representation to a European scale. 
I therefore focus on how members of the organisation construct this mode of action. What resources do they mobilise and what results do they expect from such an investment? Seizing the opportunities raised by the European agenda can prove challenging for the company at a global or transregional level, and yet this becomes the core of the European office's existence. In contrast to the image of European public affairs professionals spending most of their time engaging with other private or public professionals of the EU in Brussels, the group I observed for several months actually dedicates nearly half of its time to advocating internally that Europe is an important, if not the most important level on which to promote the company's interests. Such an investment led the chief of the European office to adopt a catchphrase emphasising his stronger dedication to EU policy than to the products he is advocating for: 'I don't sell soup or ice-cream, I bring growth back to Europe.' The creation of such a 'European point of view' is at odds with the firm's narrative at a global level, aiming to maintain its market share worldwide in a low-growth environment. In this perspective (and this is not specific to this company), cutting costs becomes prevalent and largely impacts the budget for communication, which the Euro-office relies on most.

\section{A constant enterprise of self-legitimation}

As the Brussels office is often subject to internal discrediting both from other services (business departments) and from headquarters' executives, countering this endangering criticism has been fully incorporated into the office's frame of action, and it constantly seizes opportunities to reinforce its legitimacy. The company's annual board meeting hosted in Brussels provided an example of this internal vulnerability. The event, organised each year by a different office, offers insight into the company's internal tensions and underlying challenges. The European team decided to take charge of holding the 2015 event in Brussels in order 'to show their face and demonstrate their usefulness' to top executives (as explained by the chief of the EU office), in spite of the additional workload and pressure this entailed on top of their daily tasks.

Organising and hosting this event thus presented itself as a significant opportunity for the team to demonstrate their value internally. Surprisingly, board members did not all know about the existence of the office. The geographical division of the company's operations goes beyond the EU-28 (comprising Europe as a continent, including Russia, and some Middle East countries) and is led from the company's headquarters. As the EU does not fit into operational or commercial categories, top business executives regularly question the office's relevance and suggest getting rid of it. Instead, they propose sending employees from the headquarters to Brussels at critical moments, as they did in the past.

On the day of the annual board meeting, in order to tackle this latent criticism, the chief of the Brussels office delivered an opening speech entitled 'What's Hot in Brussels?' presenting its recent landmark legislative battles, such as the 
latest 'win' in the European Parliament: reducing the test period for products containing novel food components. This speech, which was of the highest importance to the Brussels team, offered them the chance to present and promote the office's daily work. In contrast to the 'business-like' discourse of the other participants, this speech proved to be a key element of internal campaigning on the relevance of the EU level of intervention and eventually took the form of a strong pro-EU address. It notably underlined the role of the EU on issues as varied as maintaining peace, creating a first-of-its-kind political experience (worth contributing to, despite an 'ongoing stormy period'), establishing a unique policy framework in which to promote stability and an environment enabling investment on a continent scale, and serving as a key norm exporter helping to secure similar business practices worldwide.

\section{A blurred position in the company's hierarchy}

Looking at the company's organisational chart, the Brussels office does not fit into any of the traditional types of hierarchy, which historically have been structured nationally. It 'floats around' within the global communications department, which performs tasks as various as internal communication and engaging with international organisations because of how complexly it has adapted to the European level of action. This position feeds an atmosphere of mistrust towards other departments, mostly business departments, with office members often having closer ties to other employees of European organisations and even public institutions, than to those of their own employer: 'We don't belong anywhere, to any department. Business [departments] don't understand anything about Europe and its opportunities and global [HQ] doesn't want to be implicated in a strategy dealing with only one continent', explained the chief of the Brussels office, who then added, '[but] after all, we're freer that way'. This illustrates a central tension that is often underlined, which is that because of the unusual position they occupy within the organisation these employees seek to establish the legitimacy of the function they serve/ of their role.

The Brussels office remains the only one that works solely and permanently on European issues within the company-which makes Europe the group's raison d'être. This unclear position has some drawbacks, mainly the necessity of delivering results with limited resources, but at the same time it fuels the office's autonomy in the company.

\section{Creating the business case for lobbying}

In many regards, the position of the European office located away from business considerations creates tensions that are reflected in its members' jargon. Adapting to its audience, in a constant language juggle, the team in Brussels put aside EU jargon in favour of a more business-like jargon when in communication with 
the firm's other departments. On the other hand, most of the arguments delivered to regulators by the observed lobbyists avoid mentioning any particular brand. When talking about an economic sector, they prefer to discuss it in a generic or broad sense, in the logic of the de-particularisation of the produced goods, in order to blend a particularist argument into one of general interest. The celebration of the opening of new office premises in 2015 offers a vivid example of the team's distant attitude towards economic activities: designed to reflect the wishes of the company's headquarters and top business executives, the event had to include some 'brand experiences' (the distribution of goodies and limited-edition branded products). This did not exactly fit the expectations of the European public affairs team. One of them confessed that he felt uncomfortable offering daily consumer goods produced by his employer to high-level Eurocrats. Even if the tone of the event did not suit their work culture or the type of arguments they usually used with EU officials, it allowed them to organise the event on the budget of a particular brand of product rather than with the Brussels office's own resources.

Furthermore, in order to adjust to the business departments' mind-set, the outcome of lobbying activities needs to be translated into business objectives. As with any support functions of an organisation, public affairs activities themselves do not create any additional economic value. Therefore, in order to show their participation in the collective effort of creating growth, the Brussels employees developed a rhetoric of cost savings 'through policy achievements' every year. They claim that their daily work contributes to being able to avoid certain regulations that constrain the economic activities of their employer. Thus, if lobbying does not create growth, to them it still prevents the company from losing money and helps it to hold on to its market share. This internal legitimation exercise prompts the team to play a game, in which they 'make up' figures that they themselves know have their weaknesses. At the beginning of every fiscal year, each employee of the European office does a rough estimate of the cost savings that they aim to generate by means of interest representation activities. The negotiations over the office's budget for the fiscal year 2016 similarly provide an example of how daily lobbying practices had to be turned into business objectives, whereby legislative wins needed to be promoted among top management primarily by emphasising cuts to expenses and increases in profit margins.

Considered from this perspective, European public affairs employees seem to be a remote team within the company, which strives to increase its autonomy while far from the financial logic of the for-profit organisation. As with the company's competitors, most of their predecessors continue to pursue their careers within the same polity field and only exceptionally go on to occupy another position within the same organisation. This particularity reveals a certain inclination towards policy, in contrast with the employees of other departments who are more business-oriented. Viewed through the lens of a social field approach to the study of EU institutions, Brussels agents stand out as possessing a specific form of 'European institutional capital' that enables them to promote the interests of their employer while fulfilling the EU's institutional expectations. To some ex- 
tent, EU lobbyists feel closer to EU civil servants than to the agents of their company's business departments, because they share an interest with civil servants in helping each other to improve their respective positions within the field of power. The specificities of this sphere depart from the rules of other policy-making environments, which suggests the autonomisation of the European polity field, as highlighted by recent literature [Cohen 2011]. Furthermore, many of the corporate interest representatives have had professional experience within European institutions, like the European Parliament or Commission, even for a short period (internship). What is often called the 'revolving door phenomenon' adds to the porosity of institutional borders within the field, where resources and know-how circulate. The shared social characteristics of the public and private agents in the Eurocracy field clearly have the effect of blurring the line between those who regulate and set the norms and those who are regulated.

\section{b. 'A handful of employees securing a market of half a billion people'}

'Working wonders without a penny'

The financing scheme of the European office paradoxically has a very basic budget (covering only the costs of personnel, office management, and various memberships in sectorial and European federations), but it is also unlimited as long as brand units or other departments can be persuaded to cover the expenses of specific lobbying or communication activities. This mechanism largely relies on interpersonal relations between the employees of the Brussels office and the other units and those employees' acquaintance with the 'European project'. As mentioned above, the Euro-office is formally part of the global communications department; however, its position in between the global and the European (beyond EU-28 Member States) market allows it to play with shifting borders and attract available resources when needed. That is to say that its rather weak level of institutionalisation forces its employees to be able to demonstrate their legitimacy at any time, hence the crucial importance placed on their network and social capital.

The opening of the new Brussels premises was thus partly financed by the brand portfolios, as the European public affairs office accepted an 'ice cream pleasure store' and other similar 'brand experiences' at the event. The same logic applies to all the events organised by the Brussels team, which constitutes a major part of their EU-level lobbying efforts, but which could not be covered with a budget solely dedicated to the functioning of their office.

\section{Benefitting from spatial autonomy}

Contrary to the theory generally put forward, according to which lobbyists have very limited autonomy from their employer and are mere messengers, as noted above most of the company's top executives have-or are seen as having-limited 
knowledge of the activities of European public affairs employees, their actions, or the resulting decisions that are made in the company's name. It appears that those employees based in Brussels enjoy greater autonomy and are subject to a very limited system of validation. Whereas other units need to have their external appointments, public positions, or even tweets validated by an internal control system, this is not the case for the European office-which, for example, tweets independently. Reversing the social stigma, the members of the Euro-office find an objective advantage to the blurred and detached position they occupy in the company's organisational chart: outside the traditional hierarchies within the company, they possess an autonomy and authority that goes well beyond what similar positions in other business units could offer. These employees even highlight the 'start-up atmosphere' of the Brussels office despite working for an organisation that hires thousands of people. In fact, they seem to be acting to protect both their own interests (preserving their own position and work conditions in the company) and their company's.

Against this background, feedback from the company's headquarters as reported by European public affairs employees can take the form of remarks such as 'The Brussels team doesn't increase market share, is not helping the business, they are a bunch of intellectuals enjoying dinners in fancy restaurants with EU functionaries'. The Euro-team therefore continuously exercises a strategy of proving its own utility to the rest of the company. They play the role of EU ambassadors internally to promote both the relevance of the European Union level and their own jobs, and make them the right players to fulfil their task. This puts these professionals in the role of 'double entrepreneurship': an entrepreneur on behalf of both their employer's cause and the European cause.

While the uneven distribution of this European institutional capital marginalises the European public affairs employees inside their company, it also grants them some assets beyond formal hierarchies. The coordination and management of the 'Angels of Europe' across most of the nationally based offices of the company in Europe offers a powerful illustration of the accumulation and deployment of specific forms of European capital by the employees in Brussels.

\section{Managing the network of 'Angels of Europe' to become a policy entrepreneur}

Connecting and managing a wide network of (approx. 50) communications employees across Europe (including but not only public affairs professionals) so as to make them the ambassadors of Europe for their national teams is achieved in several ways: Through an 'educational' process delivered by the Brussels team outside of formal hierarchies employees of the company's offices based in most of the capitals of Europe develop European projects on top of their daily activities and progressively endorse the relevance of European policymaking and even 
contribute to reallocating national resources to European objectives. This internal European network is also structured through the mobilisation of external resources (consultants and experts) to assemble ad hoc thematic, technical subnetworks according to ongoing legislative developments.

\section{a. Educating the nascent 'Angels of Europe'}

This section focuses mainly on the informal network of employees based in offices in European Member States and outside Brussels. Most of the people considered here are engaged in activities at the local level, and, in contrast with the top executives at the headquarters, are part of business units that have an eager interest in the EU as it impacts their daily activities. For example, regulations decided at the European level will eventually be applied nationally, prompting specific lobbying activities towards government members in the implementation phase. Despite the formal hierarchy, it happens that the Brussels office not only coordinates but also delegates lobbying tasks to the national offices. ${ }^{2}$

This network also includes some employees from outside the communications sphere, working in some other department of the company, such as regulatory affairs, who want to develop specific 'European' skills. In a process resembling Europeanisation through projects [Featherstone and Radaelli 2003; Pasquier 2005], most of them are moving progressively towards EU-related public affairs activities as the European Union level gains importance for their national business activities. Once a year, this network of public affairs meets in Brussels, which gives major momentum to its affiliates.

\section{Getting socialised into the workings of the EU}

The Brussels team's development of dedicated tools for the rest of this informal network enables the company to take an active role in a wide array of policy fields, despite restricted human and financial resources available to the Brussels-based office. These tools can be as various as e-mail templates for contacting Members of the European Parliament (MEPs), monthly conference calls, interaction with experts, and constant sharing of information from EU legislative monitoring.

More specifically, the annual gathering of the Public Affairs professionals' network constitutes an occasion for both familiarisation with the codes of European polity and the transmission of European technical capital and know-how

\footnotetext{
2 This echoes a similar delegation of tasks observed between European organisations and their national members, such as the European cars trade association and its delegation of tasks to the national departments of specific companies, as described by the NGO Corporate Europe Observatory: https://corporateeurope.org/power-lobbies/2016/03/leakshows-commission-giving-inside-information-car-lobby-new-emissions-tests.
} 
(how institutions, decision-making, and negotiation processes work in the EU and lobbying techniques). The event used to be held in Strasbourg during a plenary session with a relevant issue on the agenda in order to provide a full-scale educational moment and on top of a programme dedicated to briefings on the most strongly trending EU legislative topics and to adjusting multi-level lobbying strategies. The programme broadly remains unchanged, but now takes place in Brussels, as it is the 'capital of the EU'. As an example, the peak moment of the 2016 edition was a dinner gathering of around thirty participants from the network, four MEP assistants, a consultant, and a member of the Cabinet of the First Vice-President of the European Commission (who ultimately cancelled her attendance at the very last minute). On top of this, the Brussels office provided their entire network with a short list of MEPs dealing with the main policy developments related to the company's activities. Each participant had the possibility of meeting with three pre-selected MEPs according to their geographical origin and a pre-drafted e-mail allowed them to make appointments with some of them prior to their coming to Brussels.

Initiating participants into the inner workings of the European Union appears to have been a genuine moment of accomplishment for the Brussels team that went beyond merely delivering standard presentations. The socialisation effects are envisaged as having the capacity to convert individuals from the national to the European cause. Working groups have to be didactic as well as entertaining and build on some of participants' expertise developed on a specific theme to share lessons learned with the rest of the group. Through workshops and lobbying simulation modules, lobbyists from offices in European capitals have to get used to negotiating with foreign colleagues who often have a very different understanding of what public affairs mean. Beyond the language barriermost of them speak correct English but their everyday work takes place in their national language - and in the same way as the trade union apprentices observed by A.-C. Wagner [2009], they have to learn to 'think European' and to distance themselves from national categories of analysis. Those already initiated into the know-how necessary to adequately apprehend the European Union polity field can then teach it in return. This field is thus at the same time considered to be the place where regulations and norms are negotiated, and a source of funding (EU grants for innovation, for example ${ }^{3}$ ) and work opportunities.

This annual event thus involves a real staging of 'Brussels' by those who work there aimed at producing an image of the European dimension of a public affairs profession that is rooted in a certain mythicised conception of the environment. For instance, the 2016 programme included a conference pompously called 'Europe by Those Who Made It'. While providing technical training on regulations under discussion at the European Commission (norms on food ingredi-

\footnotetext{
${ }^{3}$ As an indicator, the most recent EU funding the firm received exceeded the overall EU lobbying expenses declared annually.
} 
ents), the sessions also helped to raise the profile and underline the sophistication and the technicality of European lobbying activities.

The group performs its relation to Europe. Later, for example, they shared on the organisation's Intranet a picture of all the members pausing in front of a map of Europe. This annual event acts as a platform to display and actualise their attachment to Europe or to what they often refer to as the 'European project'. Therefore, they strongly promoted this event as a pro-European corporate ritual or jamboree, comprising staged performances and keynote presentations. For participants, these Brussels meetings create a feeling that they are contributing to the making of Europe. As participants commented in the evaluation form after the intense two-day gathering, they 'get the EU breath', 'it gives more meaning to [their] daily activities'. On the organisers' side, this is an opportunity to display their expertise and know-how-for instance, by inviting a member of the Cabinet of the First Vice-President of the European Commission to talk on a trendy topic that year which was the circular economy. For them, the workshop serves to internally justify their position and their office as a whole in the face of local and global executives and demonstrate that 'they know' and that 'they make Europe work'.

If Europe is presented as a conviction or even a mission by the European public affairs network, it is interesting to note that this conviction does not necessarily have to reflect a personal position and may be more an aspect of the role of a 'European professional' [Georgakakis and de Lassalle 2007]. However, Europe remains an evasive framework, broadly understood as involvement in the deliberate construction of a vaguely defined idea and an ability to collectively shape regulatory reforms that could be strategically adapted to appeal to diverse constituencies.

While they are already socialised into Europe by contextual elements, such as being an EU citizen, participants nonetheless reinforce this socialisation. Individuals learn to overcome the mental barriers of the national territory in which they operate daily and while doing this they adopt the structuring principles of an 'international habitus' [Wagner 1998]. Through such trainings, the public affairs professionals assume the role of Europeanisation in their respective national practice and become 'entrepreneurs of Europe' [Cohen, Dezalay and Marchetti 2007] following a logic of distinction from their peers.

In spite of the absence of a direct hierarchal link between the EU office and national offices, senior national staff willingly take part in this European 'game' under the directions of - sometimes junior-host staff within an informal hierarchy where domination occurs through the mastery of specific capital, often described as 'European resources'. In this respect, for members of the network, the EU has to be presented both as a horizon for public affairs activities and as a rather complex game. The strengthening of a structural and informal dependency between Brussels and national practices leads to the mobilisation of 'genuine' European professionals, who come from the EU public and private job market, as 
all of the actual employees have working experience in European institutions and have never worked in another company department. If some participants are in charge of European affairs in their national practice, they cannot pretend to become lobbyists in the EU policy field in their own right. Thus, these trainings reproduce the sense of Europe as inaccessible for which it is criticised: as S. Laurens [2108] has shown in the case of a European trade federation, at a company level the nascent 'Angels of Europe' are taught that Brussels is a complex bureaucracy that one cannot be a part of based simply on a traditional national affiliation.

These conclusions fully corroborate the findings of $\mathrm{H}$. Michel [Michel 2005; Michel and Robert 2010], notably in her analysis of lobbying training sessions in a real-estate federation: the trainings and all the performances around Europe lead to the designation of a function within a company or an administration and brings additional recognition to actions that were already being performed. Members of the network taking part in such events seize the opportunity to stabilise their role and further endorse it in order to become intermediaries of Europe at the national level. Their coming to Brussels results from this redefinition and stabilisation of them as specialists in European affairs who share a belief in the power of lobbying and in the power of (and need for) Europe.

\section{Building relationships of mutual dependence}

The observed informal network aims to convert employees not necessarily linked to European affairs to representatives of the European office, building on their European sensibility. They act both as information providers for the EU level and importers of reflections initiated in Brussels. If correctly sensitised through EU gatherings, people are more likely to be helpful to the Brussels office. The logic underlying the formation of this network is to make its members endorse responsibilities that are not in their job descriptions by placing their work in a wider perspective than that of the national level, within the context of 'Europe', which values their contribution. This system of rewards is largely symbolic ('people from the national [offices] are always proud to work for the EU'), but not only: they can enjoy travel to Brussels, even though it is at their own office's expense. As an example, Jana, a public affairs professional in the Czech office of the company who is in her early thirties, explains that her typical work schedule is divided between internal communication activities, which she perceives as 'dull', and engaging with national business federations and political or administrative officials, which she enjoys the most. Being the youngest of her small team, she complains both of a lack of recognition and about lobbying practices that are 'old-fashioned' (sending 'boring' written statements to journalists instead of meeting them). To this extent, being in contact with her European public affairs colleagues in Brussels gives her this extra push and confidence in engaging in face-to-face meetings as she considers this as the 'EU way', a more advanced stage of lobbying practice. Jana endorses monitoring activities for the European office and meets with assistants of some 
Czech Members of the European Parliament in their local constituency outside of her own working hours. Eventually, if a position were to become available in the Brussels bureau, she states that she would like to get it in order to work on 'more important issues' than the national ones she has dealt with so far.

Other rewards could be granting access to top executives, through the unique position of the European office, whereby it can overcome hierarchal barriers and give members of their organisation, colleagues employed in some lower positions in the firm, access to people with whom they would not necessarily be in contact. A colleague in charge of waste policy in Brussels comments, 'Finally, people are starting to like us because we give them a window to access the CEO or the President of Europe. We may convey messages concerning their national issues, or help them gain financial support on a certain project.' These connections and channels for conveying messages are also an opportunity to gain visibility inside the company beyond the national level. In that sense, the Euro-team acts as a gatekeeper to certain executives (mostly the President of Europe). Mirroring this, the team also is a gatekeeper to European Union institutions, providing information and lobbying expertise that cuts costs (through the mobilisation of internal expertise instead of external consultants) and finds back-door routes to the legislators.

As most of the daily work in Brussels consists of collecting data and following legislative developments, in return people from infra-EU practices help gather information with national relevance. For example, they aid in preparing for the rotating Presidency of the Council of the EU in order to influence the agenda-setting and to provide input on certain Members of the European Parliament. In general, they share their knowledge of the local political context on technical topics or on issues encountered in their respective markets.

Such interactions are also in place in other departments that need to have access to EU stakeholders or add a political dimension to their messaging, for which they will rely on the Euro-team. For example, the Regulatory Affairs (RA) team in charge of food improvement was recently offered the chance to communicate their achievements during a roundtable organised by the Dutch Presidency of the Council of the EU. For this purpose, even on very short notice, they called on the lobbying expertise of the person in charge of the food dossiers at the European office. Reacting to the contrast between the regulatory team's technical approach to the subject and the rules prevailing in the EU environment, the Brussels team member comments that 'they [RA] strictly have no sense of lobbying, not one ounce of politics. They have no clue. I had to rework all their messaging and soften it. Make it understandable for non-technical food staff.' As a consequence, the nutrition service will become dependent on the European office for having managed the interface with the political sphere. On the other hand, the work of the Regulatory Affairs team would be better suited to trade association meetings, which would gather technical specialists and be less marked by political considerations [Laurens 2013]. 
I can thus observe a permanent cross-collaboration between employees in Brussels and their network structured across Europe. The office members openly compare themselves to marketers of the EU 'creating the need for Europe', as much as their marketer colleagues create the need for new products of brands owned by their employer. This give-and-take type of relationships also valorises information and briefings on national markets that will be re-used by the Brussels team during meetings with EU stakeholders to palliate a lack of access to firsthand facts and make them appear as knowledgeable players.

\section{b. Creating a well-structured, yet informal, network of EU policy entrepreneurs}

Appropriating expertise from the ground

As already shown by scholars, the role of the European Commission as initiator of legislation heavily relies on external sources of information and the European policy game has tended to become even more complex in recent years, depending highly on expertise (both internal and outsourced) [Robert 2010]. Therefore, to my interviewees, whether from that firm or its competitors, the golden rule for a successful lobbying campaign is to intervene as early as possible and to bring specific input, in order to be present at the inception of legislation and see one's point of view taken into consideration. This involvement thus mostly depends on the capacity to mobilise internal expertise to be made available to the European institution staff.

As a result, my ethnographic research made it possible to observe the formation of a latent expertise: a pool of technical resources that are activated or put to rest depending on potential legislative developments. This can take the form of thematic task forces within the company whose work is intensified or slowed down with conference calls and meetings (an example of the circular economy policy below) depending on the legislative agenda. These groups do not engage directly with regulators in Brussels but help to form the company's positioning on past or upcoming topics. It permits the company and its Brussels representatives to defend a position on a variety of topics at any time, without having to formulate an official position in the rush of a public consultation, while still weighing the perception of certain topics prior to their arrival on the European political agenda.

The example of the circular economy illustrates how this process of convergence of internal skills can lead to the creation of a dedicated task force. International interrelations brought together a member of a Czech team who had previously worked on recycling topics and happened to have a technical background and an employee from the headquarters on sustainability issues on a global scale. Another member of the task force came from the Scandinavian countries' business unit, where his team had already implemented an item related to the circular economy package of legislation. This informal and ad hoc task force reported 
to the chief of the Brussels office and helped him work out a position and a lobbying strategy at the European level. When required, some of its participants would come to Brussels to meet EU officials and discuss the technical aspects of the developing policy. While cutting on costs by favouring internal players and avoiding the need to rely too heavily on external resources (public affairs consultancies), this again creates a win-win situation that gives credit both to the employees whose expertise is mobilised and to the Brussels team for its smart management of resources.

This back-up pool of experts helps compensate for the unspecialised profiles of the EU lobbyists and to provide expertise that is not directly available to them to contribute more effectively to the policy-making processes in Brussels. In addition to this legitimacy built on expertise and science, the European team members also often mobilise what can be seen as legitimacy on the ground by bringing forward arguments and precise facts on local contexts that are directly drawn from national offices to the legislators. As an example, factual inputs related to factories established in the constituency of the Members of the European Parliament they meet in Brussels are always well considered; the same goes for having details on the political events occurring in Member States or mentioning a specific anecdote related to business activities reported in the local press.

From the EU to national practices: a concerted repertoire of collective action

This concertation on European policy matters and the elaboration of dedicated strategies and decisions forms a multi-level type of lobbying articulated around multiple poles of expertise, geographies, and levels of action. It ultimately forms a multi-level representation of collective action in the company [Tilly 1984]. The analysed transnational system of shared representations occurs outside formal hierarchies between national practices, the global level, the European team, and its national network across Europe, and without a formal structure to support these activities from other business divisions.

Therefore, an informal division of labour can be observed following the distribution of EU institutional capital: between those who 'hold' European lobbying skills, those who can influence the European policy-making process, and those who actively contribute to the formation of the company's positions. This balance mirrors the divide between the temporary and the permanent agents engaged in the field of Eurocracy [Georgakakis and Rowell 2013].

\section{Conclusion}

Exploring the social conditions of this European mobilisation inside a company contributes to a better understanding of the variations in European attitudes and perceptions among European public affairs professionals as well as across various sub-entities of an organisation. The group observed in Brussels interacts 
with European stakeholders and with actors from other business units through a two-way stream of communication. The group seeks the expertise possessed by each of the other groups, and in turn reinforces this expertise rooted in another political environment. As the Brussels office of the company has now existed for twenty years, the non-institutionalisation and perpetual (re)negotiation of its position reflect a long-term tendency. Instability is in fact the rule of the game for those professionals who are bound to rely on an informal network of 'Angels of Europe' to contribute to the EU's norm-setting processes. Reversing the stigma of their formal weakness and resource dependency in the organisation's hierarchy, they draw on their multiple positioning in order to increase their power. Their image as 'the ones who make Europe work' is their primary symbolic resource, as long as the top management of the company remains convinced that favourable norms, political stability, and the overall taxation landscape in the company's biggest market (the EU single market) are important.

In this Euro-team, the development of conflicting loyalties similarly tends to legitimise conflicting representations of 'Europe', of the profession of interest representation, and of the very existence of those who perform it in a given space. Employees in Brussels work to defend the company's interests but also their own interests in order to preserve their job position. This kind of situation becomes tense when the legislative agenda slows down in the policy areas they are concerned with and when there are fewer and fewer lobbying cases. Under such circumstances, their main activity involves lobbying ... for themselves. This shows that the value of European institutional resources in lobbyists' careers is relatively limited and is mostly relevant in the field of Eurocracy. While institutions' agents are depicted as dependant on lobbyists in terms of expertise [Michon 2018], the latter occupy a position of double dependence, both on their employer and on the polity field in which they can valorise their specific capital. This idiosyncratic position allows the social agents in this study to play the role of broker between their employer and the field of their daily practices. In doing so, they nurture this very porosity between (economic) interests and the public sector, which cuts across the field.

From the perspective of the sociology of professions, this analysis tends to confirm that the métiers de l'Europe (EU professions) are becoming more professionalised as the European field of power is becoming more autonomous [Georgakakis 2002; Georgakakis and Rowell 2013]. For instance, European public affairs professionals based in Brussels do not have other work experience in the same company but are recruited in the EU. The hyper-professionalisation that is required to be involved at the European level thus results in public affairs professionals feeling closer to 'Europe' than to the interests they represent. In this sense, they turn into 'European private servants'. Fulfilling the requirements of being 'professionals of Europe' may therefore be at odds with the requirements of endorsing their company's interests. The two objectives can overlap with one another, inducing a 'double bind' effect. But, looking at the lobbyists' daily activities, what interest representatives are doing is defending their relative autonomy 
as participants in the field of Eurocracy within the corporate field. They leverage this autonomy to gain a better position in the corporate field, which is part of the wider field of power [Mills 1956]. In this perspective, the 'dual loyalties' both to the EU project and to their employer, instead of undermining each other, would seem rather to reinforce each other. Feeling closer to EU civil servants (than to the agents of their company's business departments) then becomes the condition for maintaining a distinct position in the firm.

The presented case study unveils the complexity of the European polity. It depicts the auxiliaries of EU civil servants who 'make Europe work' on a permanent and daily basis and expands beyond the permanent staff inside EU public institutions [Courty and Michel 2013: 166-167]. As shown, the presence of a company inside the European polity field and its contribution to the standard-setting processes is not self-evident and is the result of political work. This study thus offers a useful empirical reminder about European integration: Europe is also constructed by the mobilisation of the actors who contribute to the attractiveness and the legitimacy of this singular social field (with variable success as depicted). While this contribution focuses on the inner workings of a company's participation in drafting policies, it could be extended by looking at how the resources of European public affairs agents and their network of 'Angels of Europe' operate within the field of Eurocracy. For example, we could study relationships between this interest group and European Commission officials or daily practices inside the Brussels sphere of influence such as forging coalitions in specific policy sectors using the dual dimension of their European bureaucratic capital [Laurens 2018]. Indeed, it is thanks to the combination of expertise on the workings of the EU that the Brussels team members possess and the more technical resources provided by the 'Angels of Europe' network that the company is able to pursue a trusted position in the European field. In other words, it is the ability to shape input into forms that the employees of European institutions value and promote that allows the company to act across the borders between the private and public sectors. This dual form of legitimacy, held by lobbyists who occupy a permanent position in the field of Eurocracy, helps the firm to be perceived as a recognised partner to EU institutions' staff. In return, thanks to its lobbyists the firm gains the symbolic capital of being seen as a contributor to a 'Europe of peace and prosperity'.

ARMÈLE CloteAu studied political science and is now a researcher in political sociology. Her work focuses on the participation of multinational companies in food and environment policies at the European Union level and at the national level in France. Combining various qualitative methods (interviews, field ethnography) with research in public and private archives, she analyses the daily practices of social agents who promote market interests among the staff of the EU institutions who regulate the markets on which they operate. With M. Mourad she published an article on food waste policies titled 'Action publique et fabrique du consensus. La "lutte contre le gaspillage alimentaire" en France et aux Etats-Unis' in Gouvernement et Action publique. 


\section{References}

Busby, A. and K. Belkacem. 2013. "'Coping with the Information Overload":

An Exploration of Assistants' Backstage Role in the Everyday Practice of European Parliament Politics.' SSRN Scholarly Paper. ID 2290176. Rochester, NY: Social Science Research Network.

Cohen, A. 2011. 'Bourdieu Hits Brussels: The Genesis and Structure of the European Field of Power.' International Political Sociology 5 (3):335-339, https://doi.org/10.1111/j.1749-5687.2011.00137_3.x.

Cohen, A., Y. Dezalay and D. Marchetti. 2007. 'Esprits d'État, Entrepreneurs d'Europe.' Actes de La Recherche En Sciences Sociales 166-167 (1): 5, https://doi.org/10.3917/arss.166.0005.

Courty, G. and H. Michel. 2013. 'Interest Groups and Lobbyists in the European Political Space: The Permanent Eurocrats.' Pp. 166-187 in The Field of Eurocracy, European Administrative Governance Series, edited by D. Georgakakis and J. Rowell. London: Palgrave Macmillan, https://doi.org/10.1057/9781137294708_8.

Featherstone, K. and C. M. Radaelli (eds). 2003. The Politics of Europeanization. Oxford and New York: Oxford University Press, https://doi.org/10.1093/0199252092.001.0001.

Georgakakis, D. (ed.) 2002. Les métiers de l'Europe politique: acteurs et professionnalisations de l'Union européenne. Strasbourg: Presses Univ. de Strasbourg.

Georgakakis, D. and M. de Lassalle. 2007. 'Genèse et structure d'un capital institutionnel européen: Les très hauts fonctionnaires de la Commission européenne.' Actes de la recherche en sciences sociales 166-167 (1): 38, https://doi.org/10.3917/arss.166.0039.

Georgakakis, D. and J. Rowell (eds). 2013. The Field of Eurocracy: Mapping EU Actors and Professionals. Houndmills, Basingstoke, Hampshire and New York, NY: Palgrave Macmillan, https://doi.org/10.1057/9781137294708.

Georgakakis, D. 2017. European Civil Service in (Times of) Crisis: A Political Sociology of the Changing Power of Eurocrats. Palgrave Studies in European Political Sociology. London: Palgrave Macmillan, https://doi.org/10.1007/978-3-319-51792-6.

Laurens, S. 2013. 'Make it EU Friendly.' Sociétés contemporaines 89:17-46, https://doi.org/10.3917/soco.089.0017https://doi.org/10.3917/soco.089.0017.

Laurens, S. 2018. Lobbyists and Bureaucrats in Brussels: Capitalism's Brokers. Abingdon, Oxon, and New York, NY: Routledge.

Lequesne, C. and Y. Surel (eds). 2004. L'intégration Européenne : Entre Émergence Institutionnelle et Recomposition de l'état. Paris: Presses de la fondation nationale des sciences politiques.

Mazey, S. and J. J. Richardson. 1996. 'La Commission européenne : une bourse pour les idées et les intérêts.' Revue française de science politique 46 (3): 409-430, https://doi.org/10.3406/rfsp.1996.395064.

Michel, H. (ed.) 2005. Lobbystes et Lobbying de l'Union Européenne. Collection Sociologie Politique Européenne. Presses Universitaires de Strasbourg.

Michel, H. 2013. Représenter Le Patronat Européen : Formes d'organisation Patronale et Modes d'action Européenne. Brussels: P.I.E. Peter Lang, https://doi.org/10.3726/978-3-0352-6339-8.

Michel, H., C. Robert and Centre d'études et de recherches administratives politiques et sociales (Lille). 2010. La fabrique des 'Européens' processus de socialisation et construction européenne. Strasbourg: Presses universitaires de Strasbourg.

Michon, S. (ed.) 2018. Le Parlement européen au travail: enquêtes sociologiques. Rennes: Presses universitaires de Rennes.

Mills, C. W. 1999. The Power Elite. New York: Oxford University Press. 
Morival, Y. 2013. ‘Pourquoi et Comment Investir Bruxelles ? Le Temps Long de l'institutionnalisation Du Bureau Permanent Du CNPF à Bruxelles.' Pp. 93-120 in Représenter le patronat européen. Formes d'organisations patronales et modes d'action européenne. Brusells: Peter Lang.

Offerlé, M. 1994. Sociologie des groupes d'intérêt. Clefs politique. Paris: Montchrestien.

Offerlé, M. 2009. Sociologie des organisations patronales. Paris: la Découverte.

Pasquier, R. 2005. "'Cognitive Europeanization" and the Territorial Effects of Multilevel Policy Transfer: Local Development in French and Spanish Regions.' Regional E Federal Studies 15 (3): 295-310, https:// doi.org/10.1080/10438590500223269.

Robert, C. 2010. 'Les groupes d'experts dans le gouvernement de l'Union européenne.' Politique européenne 32 (3): 7-38, https://doi.org/10.3917/poeu.032.0007.

Ross, G. 1995. Jacques Delors and European Integration. New York: Oxford University Press.

Roullaud, E. 2017. Contester l'Europe Agricole. La Confédération Paysanne à l'épreuve de La PAC. Lyon: Presses universitaires de Lyon.

Shore, C. 2000. Building Europe: The Cultural Politics of European Integration. London and New York: Routledge.

Stone Sweet, A., W. Sandholtz and N. Fligstein (eds). 2001. The Institutionalization of Europe. Oxford: Oxford University Press, https://doi.org/10.1093/019924796X.001.0001.

Streeck, W. and P. C. Schmitter. 1991. 'From National Corporatism to Transnational Pluralism: Organized Interests in the Single European Market.' Politics \& Society 19 (2): 133-164, https://doi.org/10.1177/003232929101900202.

Tilly, C. 1984. 'Les origines du répertoire d'action collective contemporaine en France et en Grande-Bretagne.' Vingtième Siècle, revue d'histoire 4 (1): 89-108, https://doi.org/10.3406/xxs.1984.1719.

Wagner, A.-C. 2009. 'La fabrique de syndicalistes "européens": une enquête sur les formations européennes de la CES, The Making of "European" Trade Unionists: an Investigation Into the Training Courses of the ETUC.' Politique européenne 27: 105-127, https://doi.org/10.3917/poeu.027.0105.

Wagner, A.-C. 1998. Les Nouvelles Élites de La Mondialisation: Une Immigration Dorée en France. Paris: Presses universitaires de France. 


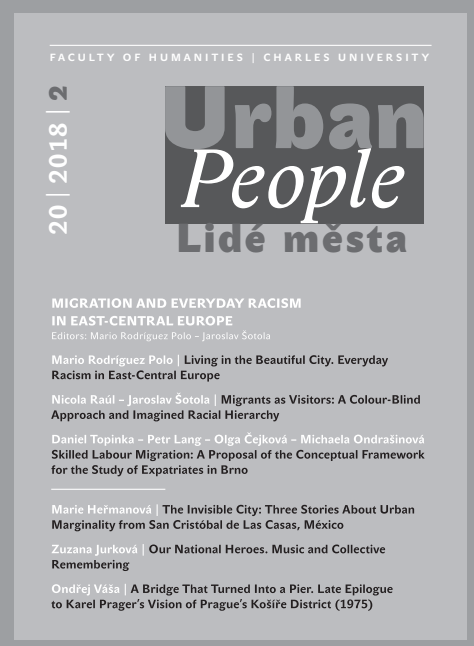

\section{URBAN PEOPLE LIDÉ MĔSTA}

is a peer-reviewed scholarly journal focused on anthropological studies with emphasis on urban studies, and related social sciences and humanities. It is published three times a year, twice in Czech (in May and December) and once in English (in September).

Published by: Faculty of Humanities of Charles University

U kř́že 8, 15800 Praha 5, Czech Republic

\section{Editors-in-chief:}

Zdeněk R. Nešpor zdenek.nespor@soc.cas.cz (Czech edition)

Hedvika Novotná hedvika.no@gmail.com (English edition)

\section{Content of last Thematic Issue:}

\section{MIGRATION AND EVERYDAY RACISM IN EAST-CENTRAL EUROPE}

$>$ Living in the Beautiful City. Everyday Racism in East-Central Europe (Mario Rodríguez Polo)

Migrants as Visitors: A Colour-Blind Approach and Imagined Racial Hierarchy (Nicola Raúl - Jaroslav Šotola)

Skilled Labour Migration: A Proposal of the Conceptual Framework for the Study of Expatriates in Brno (Daniel Topinka - Petr Lang - Olga Čejková - Michaela Ondrašinová)

The Invisible City: Three Stories About Urban Marginality from San Cristóbal de Las Casas, México (Marie Heřmanová)

$>$ Our National Heroes. Music and Collective Remembering (Zuzana Jurková)

$>$ A Bridge That Turned Into a Pier. Late Epilogue to Karel Prager's Vision of Prague's Košíře District (1975) (Ondřej Váša) 